\title{
Robert J. Sternberg, Linda Jarvin, Elena L. Grigorenko, Mądrość, inteligencja i twórczość w nauczaniu. Jak zapewnić uczniom sukces, Wydawnictwo Uniwersytetu Łódzkiego, Łódź 2018, ss. 216
}

We współczesnej pedagogice postuluje się wiele niezbędnych zmian w edukacji. Jej istotą nie może być już tylko transmisyjny sposób przekazywania wiedzy z wiodącą rolą nauczyciela jako jedynego jej posiadacza. Przede wszystkim zauważana jest potrzeba rozwijania zaangażowania i inwencji ucznia oraz konstruowania przez niego wiedzy w toku własnej aktywności. W polskiej edukacji wciąż preferowany jest podający styl nauczania, mimo popularyzacji w literaturze naukowej różnych koncepcji wspierania rozwoju uczniów w obszarze myślenia problemowego, twórczości i umiejętności praktycznych oraz uczenia ich, jak się uczyć (zob. też: Fisher, 1999; Silberman, 2005).

W nurt tych publikacji wpisuje się książka R.J. Sternberga, L. Jarvin, E.L. Grigorenko Mq̨drość, inteligencja i twórczość w nauczaniu. Jak zapewnić uczniom sukces, wydana przez Wydawnictwo Uniwersytetu Łódzkiego (Łódź 2018). Książkę rozpoczyna Wprowadzenie napisane przez prof. dr. hab. Krzysztofa J. Szmidta będącego niekwestionowanym autorytetem w zakresie pedagogiki twórczości i kreatywności. Publikację przetłumaczyła dr Elżbieta Płóciennik² naukowo zajmująca się koncepcją

1 Monika Zińczuk, Wydział Pedagogiki i Psychologii, Uniwersytet w Białymstoku, Polska, m.zinczuk@uwb.edu.pl.

2 E. Płóciennik jest autorką serii „Edukacja dla mądrości”, jaka ukazuje się nakładem Wydawnictwa Uniwersytetu Łódzkiego. Są to następujące publikacje: Rozwijanie mądrości dziecka. Koncepcja i wskazówki metodyczne, Łódź 2016; Rozwijanie mq̨drości w praktyce edukacyjnej. Scenariusze zajęć w przedszkolu i szkole podstawowej, Łódź 2016; Rozwijanie mądrości w praktyce edukacyjnej. Scenariusze zajęć dla młodzieży, Łódź 2016; Mq̨drość dziecka. Predyspozycje, przejawy, perspektywy wspierania, Łódź 2018. 
edukacji dla mądrości inspirowanej dokonaniami R.J. Sternberga (Teaching for Wisdom). Recenzentem książki była dr hab. Janina Uszyńska-Jarmoc, prof. UwB, której zainteresowania naukowe dotyczą twórczej aktywności dzieci, młodzieży i dorosłych rozpatrywanej z perspektywy zdolności, uzdolnień i postaw twórczych. Wymienione osoby swą pozycją i dorobkiem naukowym niewątpliwie wzmacniają rangę wydanej publikacji, dając jej gruntowne i sugestywne rekomendacje.

Amerykański psycholog Sternberg jest autorem wielu wpływowych i przełomowych teorii naukowych, m.in. „triarchicznej teorii inteligencji, inwestycyjnej teorii twórczości, koncepcji stylów myślenia, zintegrowanej teorii mądrości, koncepcji inteligencji praktycznej, i kilku innych (miłości, nienawiści i przywództwa” (Szmidt, 2018, s. 7). Z triarchicznej teorii inteligencji ogłoszonej przez Sternberga w 1985 r. wynika, że inteligencja powiązana jest z szybkim automatyzowaniem procesów poznawczych. Czynność wielokrotnie wykonywana automatyzuje się, co oznacza, że jej sterowanie przechodzi z poziomu globalnego, to jest wymagającego świadomej kontroli przebiegu czynności, na poziom lokalny, niekontrolowany i niewymagający wysiłku. Według autora osoby inteligentne szybciej automatyzują procesy poznawcze, dzięki czemu wykonują wiele czynności w sposób płynny, szybki, bez wysiłku i bez konieczności sprawowania nad nimi świadomej kontroli. Inteligencja w tym ujęciu oznacza możliwość korzystania z doświadczenia, używania procesów metapoznawczych do uczenia się oraz zdolność adaptacji do otaczającego środowiska, które może wymagać przystosowań w zależności od warunków społecznych i kulturowych (https://psychotertium.wordpress. com/2012/09/25/inteligencja-w-ujeciu-sternberga/ [dostęp: 10.09.2018] strona internetowa: psychotertium, 25.09.2012).

Sternberg (2003) jako pierwszy w swoich działaniach w kierunku rozwijania mądrości uczniów zaproponował zastosowanie celowo dobranych programów edukacyjnych, dostosowanych do zróżnicowanych potrzeb uczniów z różnych etapów kształcenia. Programy te opatrzył wskazówkami dotyczącymi jednoczesnego rozwijania i wykorzystania w sposób zintegrowany trzech sfer umysłu człowieka: Mądrości, Twórczości i Inteligencji (j. angielski - WICS: Wisdom, Intelligence, Creativity Synthesized). Według tej koncepcji mądrość jest jedną z cech gwarantujących właściwe zastosowanie inteligencji i twórczości w rozwiązywaniu różnych problemów, ponieważ pozwala uwzględniać i łączyć indywidualne osiągnięcia jednostki oraz dobro ogółu. Podstawową ideą modelu edukacji WICS jest teza, że ludzie potrzebują kreatywności, aby stworzyć wizję tego, dokąd chcą się udać, czyli kreować projekty, sporządzać plany, koncypować rozwiązania, a przy tym radzić sobie z ciągle zmieniającą się rzeczywistością w środowisku. Inteligencja analityczna pozwala upewnić się, czy ich kreatywne pomysły są dobre, właściwe, 
możliwe do realizacji. Inteligencja praktyczna natomiast umożliwia jednostce realizację swoich pomysłów, wprowadzenie ich w życie i przekonanie innych o ich wartości. Jednak wszystkie te czynniki łączy mądrość, która gwarantuje, że zarówno pomysły, jak i działanie będą wartościowe, użyteczne nie tylko dla jednostki, jak również pomogą w osiągnięciu wspólnego dobra etycznego (Sternberg, 2009b). Model WICS różni się od tradycyjnego modelu edukacji, który kładzie nacisk przede wszystkim na rozwijanie pamięci i umiejętności analitycznych. Klasyczne metody nauczania oraz testy zdolności i osiągnięć mają tendencję do podkreślania znaczenia przechowywanej wiedzy o faktach i podstawowych umiejętności. Taka wiedza i umiejętności są ważne. Nie można myśleć twórczo, aby wyjść poza to, co jest znane, np. jeśli nie ma się wiedzy, aby iść do przodu. Problem polega na tym, że wiedza przechowywana w pamięci może być obojętna i zasadniczo nieużyteczna. Umiejętności analityczne mogą pomóc w ocenie istniejących pomysłów, ale nie generują pomysłów własnych; nie mogą też pomóc przystosować się do szybko zmieniającego się świata, dystansując ludzi, którzy mają trudności w elastycznej adaptacji do zmieniających się wymagań (Sternberg, 2009b).

Koncepcja (Sternberg, 2009a) promuje trzy właściwości jednostki: mądrość, inteligencję oraz kreatywność, które pobudzane i stosowane jednocześnie, pozwalają wykorzystywać optymalnie pamięć, wiedzę i inne zdolności. To one tworzą wyznacznik edukacji stymulującej, której podstawowym założeniem jest ich zintegrowane rozwijanie i zrównoważone wykorzystywanie. Taka edukacja warunkuje myślenie transgresyjne, polegające na wychodzeniu poza dostarczone informacje oraz twórcze rozwiązywanie problemów oparte na ocenie dotychczasowych rozwiązań i pomysłów oraz przydatności nowych. Efektywność ich wykorzystania wzmacniana jest dodatkowo poprzez aktywność własną jednostki i zaangażowanie w zadanie.

Właśnie ta koncepcja i nurt myślenia o edukacji rozwijającej refleksyjność, samodzielność myślenia, inteligencję oraz kreatywność jest głównym przesłaniem i leitmotivem recenzowanej książki. Autorom publikacji przyświeca wizja edukacji, która umożliwia przygotowanie przyszłych dorosłych członków społeczeństwa do efektywnego rozwiązywania istotnych problemów cywilizacyjnych i problemów dnia codziennego. Publikacja pozostaje w opozycji do edukacji tradycyjnej nastawionej na dominującą rolę nauczyciela, dydaktyzm, schematyzm i kształtowanie umiejętności pamięciowych i sprawności analitycznych. Autorzy podkreślają konieczność rozwijania i doskonalenia umiejętności przewidywania, podejmowania decyzji, rozwiązywania konfliktów, myślenia i działania twórczego, rozumienia i przetwarzania informacji, aktywności w rozwiązywaniu pojawiających się problemów, kojarzenia faktów i zjawisk oraz komunikowania się i współpracy z innymi. 
Niestety, czytelnicy chcący głębiej zapoznać się, a przede wszystkim zrozumieć opisywaną koncepcję, zmuszeni będą korzystać z innych licznych dzieł i publikacji autorów oraz proponowanej przez nich bibliografii. Sama lektura części pierwszej zatytułowanej Jak uczyć mądrości, rozwijać inteligencję i twórcze myślenie zdecydowanie nie wystarcza do dociekliwego eksplorowania i dokładnego przestudiowania modelu edukacji WICS ${ }^{3}$, która w publikacji opisywana jest bardzo skrótowo, ogólnikowo i powierzchownie. Autorzy zdają sobie jednak z tego sprawę kilkukrotnie, tłumacząc się z tego faktu np. we Wprowadzeniu: „Część I jest zwięzłą prezentacją [wyróżnienie M.Z.] teoretycznego modelu ludzkiego myślenia i rozumowania [...] Wierzymy, że mądrość, inteligencja i twórczość są kluczowymi składnikami udanego życia osobistego i bardzo ważne jest, by w toku edukacji pomóc uczniom wykorzystywać wszystkie te umiejętności, innymi słowy - dokonywać ich syntezy. Dla tych, którzy chcieliby lepiej poznać teorię, jaka stoi za tym modelem, w Aneksie do Części I na końcu książki załączamy bibliografię - zawiera ona informację o artykułach i ksiqż̇kach dokładniej opisujqcych ten model [wyróżnienie M.Z.]. Znajdują się w niej także odniesienia do publikacji innych autorów, którzy badali, jak uczniowie się uczą, i proponują strategie nauczania różnych umiejętności, np. analizy i umiejętności twórczych. W części I pokrótce opisujemy model SMIT, przedstawiamy kilka argumentów [wyróżnienie M.Z.] na rzecz doniosłości nauczania rozwijającego inteligencję, twórcze podejście i mądrość [...]” (s. 29). Rozdział 2 części I „szumnie” zatytułowany Na czym polega model SMIT pełni tylko rolę obiecującą, że czytelnik wniknie w szczegóły, rozwikła i spenetruje teorię kombinacji inteligencji, twórczości i mądrości zgodną z modelem SMIT. W rzeczywistości jednak będzie miał okazję otrzymać wiedzę „w pigułce”, bowiem rozdział ten liczy cztery strony, a autorzy nadal usprawiedliwiają lakoniczność i enigmatyczność w podjętym temacie: „Książka ta ma służyć jako poręczny przewodnik, który zainspiruje nauczycieli do poszerzenia swojego repertuaru nauczania i oceniania, żeby mogli zapewnić wszystkim uczniom w klasie odnoszenie możliwie największych sukcesów. Nie oferuje jednak wprowadzenia do psychologii ani jeszcze jednego kursu inteligencji. [...] Zanim jednak zaczniemy, zwięźle streszczamy [wyróżnienie M.Z.] odmienne teorie inteligencji [...]. W największym skrócie [wyróżnienie M.Z.] można powiedzieć, że są dwa rodzaje teorii inteligencji [...] (s. 31).” Zatem to, co dla jednych czytelników być może będzie zaletą tej książki - zwięźle, dobitnie, konkretnie uchwycony sens teorii; dla innych stanie się wadą - niedostatecznie,

3 Model WICS oznacza w j. angielskim Wisdom, Intelligence, and Creativity, Synthesized, zaś w polskiej wersji książki zastosowano skrót spolszczonej nazwy modelu: Synteza Mądrości, Inteligencji i Twórczości - SMIT. 
zdawkowo, skromnie, symbolicznie, niewystarczająco, szkicowo - pozwoli jedynie fragmentarycznie i wyrywkowo zaledwie „zetknąć się” z tą koncepcją. Ja niestety należę do tej drugiej kategorii odbiorców.

Twórcy książki podkreślają tezę, że aby uczniowie odnieśli sukces nie tylko w szkole, ale również w późniejszym życiu, potrzebują czegoś więcej niż rutynowego zapamiętywania faktów i zdolności analizowania problemów. O określonym potencjale do uczenia się oraz funkcjonowania ucznia w szkolnym środowisku decydują różnorodne czynniki wskazujące na indywidualne różnice między uczniami. Istnieją różnice w poziomie intelektualnym uczniów: w sprawności uwagi, pamięci, szybkości przetwarzania informacji, poziomie i rodzaju dominującej inteligencji, zdolnościach. Różnią ich style poznawcze, style i strategie uczenia się, strategie adaptacyjne do nowych warunków nauczania. Programy szkolne preferują rozwijanie zdolności pamięciowych, zaś w mniejszym stopniu, zdaniem autorów książki, realizują doskonalenie zdolności twórczych i praktycznych. Nauczyciele powinni więc rozszerzyć swój repertuar nauczania, odpowiadając na potrzeby większej ilości uczniów o różnych stylach uczenia się. Koncepcja jest jak najbardziej słuszna, jednakże w tym samym nurcie propagowanych jest wiele innych teorii, jak choćby teoria inteligencji wielorakich autorstwa Howarda Gardnera (2002, 2009), według której o indywidualnym zróżnicowaniu uczniów świadczy między innymi to, na ile rozwinięte są poszczególne typy inteligencji odpowiedzialne za sprawność funkcjonowania aparatu poznawczego każdego z nich. Jedne mogą być bowiem dominujące, a nawet wybitnie wyspecjalizowane, podczas gdy inne będą słabo wykształcone bądź na danym etapie rozwoju ucznia pozostaną „w uśpieniu”.

Autorzy, propagując w książce swój model nauczania, wymieniają cztery powody jego skuteczności oparte na wieloletnich badaniach empirycznych. To przede wszystkim tworzenie przyjaznego środowiska uczenia się, w którym uczniowie odkrywają i doceniają wzorce swoich uzdolnień. To także gwarancja lepszego zapamiętywania materiału nauczania poprzez zwielokrotnione kodowanie informacji w sposób analityczny, twórczy i praktyczny. Zróżnicowanie uczniów w jednej klasie szkoły ogólnodostępnej jest zazwyczaj bardzo duże, a model ten pozwala dotrzeć do szerokiego zakresu umiejętności uczniów, dając im szanse wykorzystywania swoich mocnych stron i kompensowania słabych. Czwartym powodem jest wzrost motywacji ucznia, bowiem nauczanie zachowujące równowagę między różnymi typami aktywności skuteczniej przyciąga ich uwagę i staje się ciekawsze.

Ciekawą propozycją skierowaną do nauczycieli jest zamieszczone ćwiczenie służące do zbadania własnego wzorca mocnych stron mające na celu uświadomienie preferencji w ocenianiu rozwiązywanego hipotetycznego zadania w od- 
niesieniu do czterech sfer: preferencji pamięciowych, analitycznych, twórczych i praktycznych. Ćwiczenie to zawiera 10 pytań z różnych dziedzin wiedzy, a więc jest adresowane do nauczycieli uczących różnych przedmiotów. Z drugiej jednak strony np. matematykowi trudno będzie jednoznacznie opowiedzieć się, jakie czynności chciałby wykonać w zakresie wiedzy geograficznej na temat Alp czy zasad harmonii na lekcjach muzyki. Autorzy są tego świadomi, uprzedzając: „w przypadku wszystkich zadań przyjmij, że studiowałaś lub studiowałeś te tematy i orientujesz się w nich, nawet jeśli w rzeczywistości nic nie wiesz o grze w piłkę nożną i nie umiałabyś lub nie umiałbyś jej porównać z futbolem amerykańskim” (s. 35). Trzeba więc od razu przyjąć założenie, że to nie miarodajny „test”, a raczej ćwiczenie uruchamiające myślenie o preferowanym typie uzdolnień.

Druga część książki Jak i dlaczego rozwijać inteligencję, która zapewni odnoszenie sukcesów dobitnie świadczy o tym, że to przewodnik metodyczny dla nauczycieli. Czytelnicy oczekujący wywodów o roli i znaczeniu rozwoju inteligencji w nauczaniu i uczeniu się będą rozczarowani. Wstępy teoretyczne stanowią jedynie kilku akapitowe zasygnalizowanie problematyki. To moim zdaniem minus tej publikacji. Zasadniczy trzon tej części stanowi bogaty repertuar ćwiczeń ukierunkowany na cztery typy odmiennych umiejętności myślowych: pamięć, umiejętności analityczne, twórcze i praktyczne.

Podrozdział Jak rozwijać umiejętności pamięciowe zawodzi swą zawartością merytoryczną w porównaniu do pozostałych typów umiejętności, pozostawiając pewien niedosyt. Autorzy nie udostępniają tu konkretnych ćwiczeń i zadań odnosząc się do przykładów lekcji z różnych przedmiotów nauczania: języka i literatury, nauk przyrodniczych, matematyki i nauk społecznych, tak jak czynią to w pozostałych podrozdziałach. Być może wychodzą z założenia, że nauczyciele mają bogate doświadczenie w tradycyjnym sposobie nauczania preferującym umiejętności pamięciowe, a więc jest to zbędne. Ta teza przecież cały czas przewija się w książce. Jednak akurat w tym miejscu warto było pokazać możliwości usprawniania pamięci na konkretnych przykładach, co mogłoby pomóc nauczycielom zweryfikować strategie nauczania w zakresie tych umiejętności. Na tzw. „osłodę” autorzy proponują kilka ogólnych mnemotechnik, które zamieszczone są w Aneksie do części II (to jednak nadaje inny tok studiowania tego podrozdziału w porównaniu z innymi). Ponadto autorzy nie wyjaśniają definicji mnemotechnika, co wydaje się w tym miejscu konieczne i pożądane. Tak więc czytelnik otrzymuje ogólnikową wiedzę dotyczącą doskonalenia umiejętności pamięciowych, dostępną w wielu innych dostępnych pozycjach literaturowych dotyczących tej tematyki. 
Pozostałe podrozdziały stanowią bogaty zbiór ćwiczeń i zadań z prostą instrukcją ich wykonania. Autorzy twierdzą, że zakres ich treści odnosi się do różnych poziomów nauczania. Z pewnością tak jest, jednakże nauczyciel chcący z nich skorzystać sam musi określić i wybrać dane ćwiczenie pasujące do szczebla kształcenia, na którym pracuje. Zamieszczone propozycje są tu bowiem „rozproszone” i nie jest zaznaczony poziom wieku uczniów, numer klasy czy choćby typ szkoły czyli z jakimi konkretnie dziećmi, uczniami i na jakim poziomie kształcenia można te ćwiczenia wykorzystać. Polski nauczyciel może stanąć przed dodatkowym utrudnieniem w tej decyzji wyboru, bowiem zadania są konstruowane na bazie doświadczeń nauczycieli pracujących „na różnych poziomach kształcenia, w rozmaitych częściach Stanów Zjednoczonych i za granicą” (s. 21). Problematyczne może być przełożenie treści niektórych zadań na polskie realia, a dodatkowo usytuowanie ich w odpowiednich podstawach programowych. Pozostaje mieć nadzieję, że różnice kulturowe między szkołą polską a amerykańską dadzą się zniwelować poprzez twórczą i kreatywną postawę polskiego nauczyciela, który może stać się kreatorem własnych pomysłów na tworzenie podobnych zadań i ćwiczeń, inspirując się zawartością niniejszej książki. Do tego zresztą jej autorzy gorąco zachęcają.

Mój niedosyt dotyczy jeszcze kwestii prezentacji ćwiczeń i zadań w obrębie tylko czterech nauk: języka i literatury, nauk przyrodniczych, matematyki i nauk społecznych. Uważam, że brakuje nauk o mediach i technologiach informacyjnych, bo przecież jednym z priorytetowych celów współczesnej szkoły jest przygotowanie uczniów do życia w społeczeństwie informacyjnym. Komputery i technologie teleinformatyczne stwarzają możliwości indywidualizacji i personalizacji kształcenia, dostosowania tempa, czasu i sposobu przyswajania wiedzy przez ucznia do jego zdolności psychofizycznych. Stanowią nowoczesną pomoc w tworzeniu przyjaznego środowiska dla uczenia się i przedstawiania wiedzy, która stale ulega zmianie i rozwija się w świetle nowych danych doświadczalnych. Ponadto nie jest dostrzegana i doceniana integracja TI z innymi dziedzinami edukacji, mimo że technologie stają się nieodłącznym elementem każdego obszaru nauczania. Integracja TI z każdą dziedziną nauki powinna znaleźć odzwierciedlenie w edukacji. Technologia informacyjna nie może być już nauczana jedynie jako odrębny przedmiot, musi pojawiać się jako nieodzowny element w nauczaniu każdego przedmiotu. Z uwagi na ciągły rozwój i zmiany w technologii, niewystarczające staje się podstawowe przygotowanie, niezbędna jest ciągła aktualizacja umiejętności i nabywanie biegłości. Ćwiczenia takie jak np.: nagrywanie filmów, tworzenie bloga na dany temat, organizacja naukowego czatu, dyskusja na naukowych forach, wspólne opracowanie hasła w Wikipedii, praca grupowa nad dokumentem elektro- 
nicznym, komunikacja w formie tele- lub wideokonferencji, przygotowanie prezentacji multimedialnej czy wreszcie wykorzystanie gotowych, profesjonalnych, edukacyjnych programów multimedialnych z pewnością rozwija umiejętności pamięciowe, analityczne, twórcze i praktyczne. W recenzowanej książce w tej dziedzinie nauk panuje swoiste milczenie. Brak wyodrębnienia ćwiczeń w obrębie problematyki TI, nie mówiąc już o integracji takich zadań z pozostałymi rodzajami nauk i treści wyróżnionych w publikacji to znaczne niedociągnięcie.

Podobne wątpliwości nasuwa brak ćwiczeń typowo przypisanych do obszaru sztuki. Autorzy wyszli jednak z założenia, że zajęcia plastyczne, muzyczne, itp. odbierane w sposób dosłowny spłycają zrozumienie typowo twórczego podejścia do zadania. Przyznają, że: „To prawda, malowanie, rzeźbienie lub wykonanie kolażu wymagają twórczego podejścia. Jest ono jednak potrzebne także do napisania wiersza lub krótkiego opowiadania [...]. Bycie twórczym nie tylko sprzyja wymyślaniu nowych idei (na jakimkolwiek polu). Jest także zdolnością, która umożliwia zajmowanie się nowymi sytuacjami lub problemami, z jakimi nigdy wcześniej nie mieliśmy do czynienia” (s. 65). Być może z tego też powodu w książce nie znajdziemy gotowych ćwiczeń standardowo artystycznych.

Część trzecia książki Jak integrować nauczanie z ocenianiem upomina o konieczność wzajemnego dopasowania praktyki nauczania i praktyki oceniania. Autorzy postulują o równowagę sprawdzania umiejętności myślenia analitycznego i umiejętności pamięciowych oraz zdolności do myślenia twórczego i praktycznego poprzez wiele ciekawych przykładów, odnosząc się znów do treści poszczególnych przedmiotów w obrębie proponowanych nauk w części drugiej. Cennym wątkiem jest problematyka opracowywania sprawdzianów zarówno w formie zadań wielokrotnego wyboru, jak i otwartych. W tym miejscu jednak nasuwa się myśl, jak wiele strategii należy przyjąć, aby na jednej lekcji zadbać o wszystkie umiejętności. Autorzy nie podają bowiem zadań ukierunkowanych na rozwijanie tych zdolności równocześnie w jednym ćwiczeniu. Prowadzi to do wykorzystania na jednej lekcji co najmniej czterech rodzajów ćwiczeń i równolegle czterech strategii ich oceniania - co, mówiąc w uproszczeniu, staje się zadaniem trudnym i wymagającym, ale twórczym i kreatywnym.

Jak i dlaczego uczyć mądrości to czwarta część książki. Od razu nasuwa się pytanie dlaczego autorzy dokonali takiej kompozycji w strukturze całości publikacji, bowiem tytuł książki stawia jednak mądrość na pierwszym miejscu. Problematyka mądrości jako „klamra spinająca” ich koncepcję edukacji Teaching for Wisdom mogła być usytuowana w początkowej części publikacji. Autorzy tłumaczą, jak umożliwić uczniom rozwijanie trzech umiejętności myślowych opartych na mądrości: myślenia refleksyjnego, myślenia dialogicznego i myślenia 
dialektycznego, które powinno prowadzić do zwiększenia aktywności uczniów w różnorodnych sferach. Podają również wskazówki będące ogólnymi zasadami uczenia i kształtowania mądrości w szkole w różnych obszarach treści. W tej części nauczyciel jest pobudzany do osobistej refleksji dotyczącej sposobu odwzorowania omówionych wskazówek we własnym sposobie nauczania. To może być niełatwe zadanie, gdyż podawane przykłady nauczania „myślenia mądrościowego” są intuicyjnymi podpowiedziami, a sposób ich realizacji należy do inwencji własnej, aczkolwiek warto je podjąć, by krytycznie spojrzeć na uczenie mądrości poprzez pozwolenie uczniom czynnego doświadczania podejmowania mądrych decyzji, a nie tylko poprzez mówienie uczniom o mądrości.

Część piąta książki zatytułowana Synteza. Jak pomóc uczniom osiagnąć $w$ życiu sukces i spełnienie brzmi nieco patetycznie. W rzeczywistości jest oszczędnym i dość zdawkowym podsumowaniem całości problematyki. Szczególnie wartościowy wydaje się rozdział traktujący o tym, jak utrzymać równowagę między czynnościami ukierunkowanymi na różne typy umiejętności. Przynosi on przynajmniej częściowe „uspokojenie” w kwestii wątpliwości, jak poradzić sobie z wprowadzaniem różnorodnych zadań podczas lekcji, o czym wspomniałam wcześniej. Autorzy proponują schemat w formie prostej tabeli do uzupełnienia pozwalający ocenić, na które typy umiejętności myślowych (w zakresie czynności pamięciowych, analitycznych, twórczych i praktycznych) nakierowana jest nasza lekcja lub szersza jednostka programu nauczania. Dodatkowo zachęcają do jawnego wyjaśniania uczniom, że proponowane są im czynności ukierunkowane na różne mocne strony różnych osób w klasie, dzięki czemu poszerzą swój repertuar poznawczy. W zasadzie całość treści zawartych w publikacji można sprowadzić do czterech zasad twórczego i praktycznego nauczania: (1) zachować odpowiednie proporcje i równowagę między nauczaniem analitycznym, twórczym i praktycznym; (2) uczyć uczniów, jak myśleć analitycznie, twórczo i praktycznie; (3) projektować doświadczenia analitycznego, twórczego i praktycznego uczenia się, które pomagają uczniom poznawać treści programu, zamiast projektować takie doświadczenia jako „dodatki”; (4) sprawdzać, czy uczniowie osiągnęli cele uczenia się, łącząc sposoby oceniania nakierowane na różne umiejętności myślowe (s. 184). Nie znajduję uzasadnienia, dlaczego w tej części autorzy jakby „zapomnieli” o rozwijaniu umiejętności pamięciowych - w niektórych schematach je pominęli (Tabela 52, 54, 57, s. 176-182), zaś w niektórych zaliczyli je zamiennie do czynności analitycznych (Tabela 53, 55, s. 177-179).

Po przejściu przez wszystkie części książki zapełnionych gęsto ćwiczeniami, przykładami, zadaniami, pytaniami skłaniającymi do własnych wniosków umysł 
czytelnika może być nieco zmęczony. Momentami lektura tej książki jest nużąca (poprzez nadmierną liczbę ćwiczeń z różnych dziedzin nauk), fragmentami pozostawia niezaspokojenie poznawcze (poprzez oględność i skrótowość w prezentacji teorii), są natomiast wątki wymagające twórczego i zaangażowanego podejścia zmuszającego do przewartościowania swych schematów, nawyków i przyzwyczajeń w nauczaniu. To wszystko sprawia, że lektura tej książki jest ciekawa, inspirująca i czytelnik na pewno nie będzie się nudził. Poza tym warto studiować ją kilkukrotnie, nie sposobem czytania „od deski do deski”, a powracając w różne części wybiórczo, w zależności od potrzeb zrozumienia danych kwestii.

Pamiętać należy, że książka stanowi przede wszystkim przewodnik metodyczny, a więc ma wymierną wartość praktyczną i powinna służyć doskonaleniu kompetencji nauczycieli poprzez wzbogacenie ich warsztatu metodycznego o konkretne i nowe propozycje sposobów rozwijania mądrości, inteligencji i twórczości uczniów. Ponadto ukazuje nauczycielom potrzebę integracji rożnych sfer aktywności ucznia, dzięki czemu możliwa jest realizacja rozwoju każdego z uczniów w zróżnicowanych warunkach środowiskowych poprzez rozwiązywanie różnorodnych problemów. I taką rolę bez wątpienia ta publikacja spełnia. Na podkreślenie zasługuje również fakt, iż używany przez autorów, będących wybitnymi profesorami psychologii, język jest przystępny i zrozumiały dla każdego czytelnika, który zechce sięgnąć po ich książkę. Ta komunikatywność świadczy o szacunku dla przeciętnego odbiorcy.

Książka zachęca do prób poszukiwania i wdrażania innowacyjnych rozwiązań metodycznych, pomocnych w procesie rozwijania refleksyjności, twórczości i kreatywności uczniów. Patronuje jej cały czas teoretyczny model ludzkiego poznawania (myślenia i uczenia się) jako synteza mądrości, inteligencji i twórczości. Jest skierowana przede wszystkim do nauczycieli, wychowawców i pedagogów, konsultantów i doradców metodycznych. Z powodzeniem mogą z niej także skorzystać studenci pedagogiki, niezależnie od specjalności, którą studiują, bowiem treść publikacji wskazuje na jej wielostronne zastosowanie zarówno w aspekcie teoretycznym, jak i praktycznym.

\section{Bibliografia}

Fisher, R. (1999a). Uczymy, jak się uczyć. Warszawa: WSiP.

Fisher, R. (1999b). Uczymy, jak myśleć. Warszawa: WSiP.

Gardner, H. (2002). Inteligencje wielorakie. Teoria w praktyce. Poznań: Wydawnictwo Media Rodzina. 
Gardner, H. (2009). Inteligencje wielorakie. Nowe horyzonty w teorii i praktyce. Warszawa: Wydawnictwo Laurum.

Inteligencja w ujęciu Sternberga. 25.09.2012. Pobrane z: https://psychotertium.wordpress. com/2012/09/25/inteligencja-w-ujeciu-sternberga/

Silberman, M. (2005). Uczymy się uczyć. Gdańsk: GWP.

Sternberg, R.J. (2003). Wisdom, Intelligence, and Creativity Synthesized. Cambridge: Cambridge University Press.

Sternberg, R.J. (2009b). Wisdom, Intelligence, and Creativity Synthesized: A New Model for Liberal Education, Liberal Education, Fall 2009, Vol. 95, No. 4, Pobrane z: https:// www.aacu.org/publications-research/periodicals/wisdom-intelligence-and-creativitysynthesized-new-model-liberal

Sternberg, R.J., Jarvin, L., Grigorienko, E.L. (2009a). Teaching for Wisdom, Intelligence, Creativity, and Success. Thousand Oaks: Corwin A SAGE Company.

Szmidt, K.J. (2018). Wprowadzenie. W: R.J. Sternberg, L. Jarvin, E.L. Grigorenko, Mqdrość, inteligencja i twórczość w nauczaniu. Jak zapewnić uczniom sukces (s. 7), Łódź: Wydawnictwo Uniwersytetu Łódzkiego. 